\title{
LV. On the acid contained in the North American columbite
}

\section{Henry Rose}

To cite this article: Henry Rose (1847) LV. On the acid contained in the North American columbite, Philosophical Magazine Series 3, 30:202, 360-361, DOI: 10.1080/14786444708647191

To link to this article: http://dx.doi.org/10.1080/14786444708647191

Published online: 30 Apr 2009.

Submit your article to this journal $₫$

Џ Article views: 3

Q View related articles $\square$ 
might be measured, would yield at $2000^{\circ}$ a light suitable for most purposes. Moreover, it would be very easy to form from it an available photometer, by screening portions of the shining surface. An ingenious artist would have very little difficulty, by taking advantage of the movements of the lever, in making a self-acting apparatus, in which the platinum should be maintained at a uniform temperature, notwith. standing any change taking place in the voltaic current.

University, New York, Feb. 27, 1847 .

LV. On the Acid contained in the North American Columbite. By Henry Rose*.

THE columbite of North America has the same crystalline form as that from Bodenmais in Bavaria, but is distinguished from it in general by a far lower specific gravity; however, we find the same difference in the specific gravity of the American mineral as occurs in the different crystals of the Bodenmais columbite. The lightest crystals from the last locality have the same specific gravity $(5 \cdot 704)$ as the heaviest crystals from North America (5•708).

I have already communicated two analyses of North American columbites, of one of which however it was doubtful whether it came from America. The following analysis of American columbite was made by $M$. Grewink in my laboratory; it yielded,-

$$
\begin{aligned}
& \text { Acid . . . . . . . . . . 80.06 } \\
& \text { Protoxide of iron . . . . . . } 1259 \\
& \text { Protoxide of manganese . . . . 5.97 } \\
& \text { Oxide of tin . . . . . . . . } 0.96 \\
& \text { Oxide of copper and lead . . . } \\
& \overline{100.02}
\end{aligned}
$$

The specific gravity in fragments was $5 \cdot 323$; in powder, $5 \cdot 3202$.

This columbite comes nearest in composition and also in specific gravity to that examined by M. Schlieper.

I have on a former occasion shown that the different specific gravity of the crystals of the Bavarian columbite was owing to the different proportions of niobic and pelopic acids which are found in the different crystals. The specific gravity of these two acids is widely different, but unequally so, according to the temperatures to which they have been exposed previous to weighing.

Owing to want of material, I found it impossible to make a

\footnotetext{
* Translated from Poggendorf's Annalen.
} 
Abstract of Meteorological Observations in Brazil. 361

thorough examination of the two acids which are contained in the North American columbite: I very soon ascertained, after the discovery of niobic acid, that this was the principal acid constituent in the American columbite, but I could not determine whether it was mixed with pelopic or with tantalic acid; I therefore addressed myself to Mr. B. Silliman of Newhaven, who with the greatest readiness procured me a very considerable quantity (half a pound) of this now very rare mineral.

A large quantity of this columbite was used for the preparation of the acid. When treated in the same manner as that from the Bavarian colmmbite, it proved to consist principally of niobic acid combined with pelopic acid; but the amount of the latter was far smaller than in the Bodenmais mineral, so that I do not think it would have been possible for me to have examined the properties of pelopic acid so completely as was necessary in order to recognise it as an essentially distinct acid from tantalic acid, if I had had only the American mineral at my disposal. But both the acids were so perfectly identical in all their properties with the two acids prepared from the Bodenmais mineral, that I did not find the least difference, even as regards the specific gravity.

As the specific gravity of pelopic acid is considerably higher than that of niobic acid, when the two are heated in the same manner, the higher specific gravity of the Bavarian columbite is thus satisfactorily explained.

I have moreover found small quantities of tungstic acid in the acids from the American columbite, as well as in those from the Bodenmais mineral.

LVI. Abstract of Mcteorological Observations made during the year 1846 at Gongo Soco, in the interior of Brazil. By William Jony Henwood, F.R.S., F.G.S., Member of the Geological Society of France, Chief Commissioner of the Gold Mines of Gongo Soco, Catta Preta, and Antonio Pereira, \&c. \& c.*

THAVE nothing to add to what has been already said $\uparrow$ 1 respecting the locality and the positions of the instruments. I have again to thank Captains Blaney, Luke and Guy, for the continuation of their midnight observations, as well as for a second series, made at 3 A.M.

* Communicated by the Author.

† Phil. Mag. 1846, xxviii. pp. 364, 366. 